\title{
Vietnamese Consumer Attitudes towards Smartphone Advertising
}

\author{
Ha Nam Khanh GIAO, Bui Nhat VUONG2
}

Received: March 01, 2020 Revised: March 21, 2020 Accepted: April 03, 2020

\begin{abstract}
This research examines four specific objectives: (1) identifying factors that affect Vietnamese consumer attitudes towards smartphone advertising, (2) measuring the level of impact of the factors, (3) testing the difference of attitudes among groups of consumers with different characteristics in terms of gender, age, income, and academic level, and (4) proposing some managerial implications to have better Vietnamese consumer attitudes towards smartphone advertising. The study uses the online survey form via e-mail and Facebook in a convenience sampling method; the subjects surveyed are between the ages of 18 and 35, and all are in urban areas in Vietnam, and are using smartphones and accessing the internet and other phone applications. A sample of 490 respondents were valid and used for processing. The study employs a combination of qualitative and quantitative methods to analyze exploratory factors and linear multiple regression. The results reveal that there are five main factors affecting Vietnamese consumer attitudes towards smartphone advertising positively, arranged by reduced importance: entertainment, informativeness, credibility, non-irritation, permission and control. From that, the study offers some managerial suggestions for smartphone advertisers to improve their strategies and tatics to enhance their customer service, so that the smartphone advertising can attract people and help Vietnamese consumer in their buying behavior.
\end{abstract}

Keywords: Smartphone, Advertising, Smartphone Advertising, Vietnam, Consumer Attitudes

JEL Classification Code: B16, M10, M31, M37

\section{Introduction}

Mobile marketing is not a new concept, but in Vietnam, mobile marketing is actually known and applied in recent years. The number of telephone subscribers registered and operating nationwide at the end of June 2019 was 148.5 million, of which mobile phones accounted for 134,5 million, and the country had 121.12 million smartphone subscribers generating traffic $(90 \%)$, in which $3 \mathrm{G}$ and $4 \mathrm{G}$ subscriptions accounted for 51.13 million (34\% of total subscribers) (Loc

\footnotetext{
1 First Author and Corresponding Author. Dean, Faculty of Air Transport, Vietnam Aviation Academy, Vietnam [Postal Address: A65 Nam Thong 1 Town, Phu My Hung Zone, Tan Phu Ward, District 7, Ho Chi Minh City, 729000, Vietnam] Email:khanhgiaohn@yahoo.com

2 Lecturer, Faculty of Air Transport, Vietnam Aviation

Academy, Vietnam. Email: nhatvuong1@gmail.com

(c) Copyright: The Author(s)

This is an Open Access article distributed under the terms of the Creative Commons Attribution Non-Commercial License (http://Creativecommons.org/licenses/by-nc/4.0/) which permits unrestricted noncommercial use, distribution, and reproduction in any medium, provided the original work is properly cited.
}

\& Giang, 2019). It shows that the demand for smartphone increases sharply, and provides good opportunities for marketers.

Kaplan (2012) defines mobile marketing as "any marketing activity conducted through an ubiquitous network to which consumers are constantly connected, using a personal mobile device", while for Heikki and Matti (2005), mobile marketing is a multi-channel online marketing technique focused at reaching a specific audience on their smartphones, feature phones, tablets, or any other related devices through websites, E-mail, SMS and MMS, social media, or mobile applications. According to Matti (2008), mobile marketing can provide customers with time and location-sensitive personalized information that promotes goods, services, appointment reminders and ideas. Smartphone users are target customers of many high-end brands. The use of smartphones to access the Internet, check email, and interact with friends, becomes popular with Vietnamese consumers. Therefore, advertising via smartphone is considered a potential advertising channel in the Vietnamese market. However, many customers still feel annoyed, even feel defrauded 
by unreliable ads via SMS and spam messages. The study of consumer attitudes toward smartphone advertising has become very necessary.

Scholars studied much services (Giao, 2018a) and online transactions (Vuong \& Giao, 2019; Giao, Vuong, \& Quan, 2019; Giao, Hoai, \& Vinh, 2019, Giao, 2020; Tham, Dastane, Johari, \& Ismail, 2019; Kussusanti, Tjiptoherijanto, Halim, \& Furinto, 2019; Lee, Kwag, \& Potluri, 2015; Jun, Lee, \& Jung, 2019), while others have examined consumer attitudes toward short messaging service advertising and television advertising (Carroll, Barnes, Scornavacca, \& Fletcher, 2007; Cheng, Blankson, Wang, \& Chen, 2009; Rettie, Grandcolas,

\& Deakins, 2005; Tsang, Ho, \& Liang, 2004; Giao, 2018b), but different attitudes on mobile advertising can affect consumer involvement toward mobile advertising depending upon message content. Therefore, studying the effects of advertising attributes on consumer attitudes toward mobile advertising is an important issue. The primary purposes of this study is to determine the elements affecting Vietnamese attitudes toward mobile advertising. It will help marketers maximize the potential of this marketing communication medium and apply it in Vietnam, and contribute information that can be used to plan strategy and take appropriate decision.

\section{Literature Review}

\subsection{Concept of Smartphone Advertising}

According to Kotler, Keller, Ang, Tan, and Leong (2018), the integrated promotion mix has five main tools: advertising, promotion, personal sales, public relations (PR), direct marketing. In particular, advertising is construed as any form of non-personal introduction and promotion of ideas, products or services determined by a donor (including television advertising, printing, Internet, outdoor advertising,

..). As defined in the Ordinance of the Standing Committee of the National Assembly No. 39/2001/PL-UBTVQH10 (16 Nov 2001), advertising is the introduction to consumers of business activities, goods, which includes services for profit and non-profit purposes.

According to Wikipedia, the smartphone is a concept that refers to a smartphone that integrates a smart operating system platform with a host of advanced features in computing and connectivity based on the underlying smartphone platform. Mobile Marketing Worldwide defines: "Mobile marketing is the use of smartphones as an information, communication and entertainment channel connecting businesses and consumers. Mobile marketing is an automatic, direct, interactive, object-oriented marketing channel at anytime, anywhere".
According to the Mobile Marketing Association (MMA, 2014), smartphone advertising can be divided into four main categories: (1) advertising through the Short Messaging Service (SMS) or Multimedia Messaging Service (MMS), (2) advertising on the mobile web, (3) advertising through mobile applications, and (4) television commercial (TVC). Another way to advertise through smart devices is with the use of Quick Response Code (QR code), but this is a technique that requires consumers to act when interested in an advertisement.

\subsection{Attitude towards Smartphone Advertising}

According to Kotler et al. (2018), attitude is a positive evaluation of a person's feelings and tendencies toward an object or idea. Attitude in each person forms a frame of thought that likes or dislikes an object at the same time accepting or refusing, or leaving that object. Attitude makes people behave in accordance with similar objects. Because attitudes exist in the form of thinking, it is difficult to change, and to change a particular attitude component that may require the intervention of many other components. Attitudes are also defined as "a lasting, general evaluation of people (including oneself), objects, advertisements, or issues" (Solomon, 2004).

Attitude towards advertising is a fundamental and basic concept of one of the factors that determines attitudes toward any particular advertisement (Lutz, 1985). The attitude of a consumer or an individual toward any form of advertising is also influenced by attitudes toward publicity (Lutz, 1985).

Chakrabarty and Yelkur (2005) defined attitudes toward advertisements as consumers' predisposition to respond to a specific message positively or negatively. The attitudes are related to both mobile advertising and the approach used for delivery (Chowdhury, Parvin, Weitenberner,

$\&$ Becker, 2010). Some scholars have described mobile advertising as permission-based, incentive-based, and location-based (Zoller, Housen, \& Matthews, 2001; Tsang et al., 2004). If consumers are ready and reach agreement about receiving message, it is called permission-based mobile advertising. Incentive-based advertising messages offer consumers a specific amount of monetary value. And locationbased advertising is applied to deliver messages to specific designated consumer locations like mobile phone (Wanmo, 2010). Simultaneously, it indicates that consumers commonly show negative attitudes toward mobile advertising except that "they have specifically consented to it, and there is a direct relationship between consumer attitudes and consumer behavior" (Tsang et al, 2004). Since messages from consumers' service providers are evaluated more highly and trustworthy than from others, it is necessary for the providers to focus on selecting, 
defense as well as guarantee for their consumers (Carroll et al., 2007).

McQuail (1983) defines entertainment as "the ability to fulfill an audience's needs for escapism, diversion, aesthetic enjoyment, or emotional enjoyment". Entertainment advertising functions as social messages to make positive impression on consumers (Shavitt, Lowrey, \& Haefner, 1998). Entertainment plays an important role in mobile marketing, especially, in mobile advertising entertainment is shown as a sensation of pleasure regarding to messages consumers have (Unal, Erics, \& Keser, 2011). Similarly, Tsang et al. (2004) claimed that entertaining advertising messages also have an influence on consumers' attitudes toward mobile advertising. The entertainment value in mobile advertising was well perceived as one of the most crucial factors affecting consumers' attitudes toward advertisements by Unal et al. (2011).

Informativeness can be defined as "the ability of advertising to inform consumers of product alternatives so that purchases yielding the greatest possible satisfaction can be made" (Ducoffe, 1996). The informativeness notion is briefly capability of advertisements in which companies can transmit updated, timely and easily approachable information to consumers (Altuna \& Konuk, 2009). Ducoffe (1996) considered informativeness of advertisements a feature affecting consumers' satisfaction and their buying decisions. Informativeness of advertising information is also closely associated with advertising value when the message is sent via traditional media vehicles (Ducoffe, 1995; Zabadi, Shura, \& Elsayed, 2012). Tsang et al. (2004) concluded that perceived informativeness does have an impact on consumers' attitudes toward mobile advertising in general.

An advertisement is called irritation when it only causes consumers nuisance, dissatisfaction and illiberality (Aaker \& Bruzzone, 1985). Irritation refers to consumers' attitudes, which include only negative aspects toward mobile advertising (Altuna \& Konuk, 2009). Ercis and Ercan (2011) considers irritation one of the most crucial causes that make consumers censure advertisements. Once advertisements are realized irritating or annoying, consumers will change their attitudes negatively toward the products which are advertised (Wong \& Tang, 2008).

In advertising, credibility is defined as the extent of consumers' belief in what retailers advertise their brands (Mackenzie \& Lutz, 1989). Credibility is identical to consumers' reliance on truthfulness and verisimilitude of company's advertisement in the definition by Chowdhury et al. (2010). Credibility has been found in several findings to affect positively attitude toward mobile advertising (Zabadi et al., 2012; Tsang et al., 2004; Haghirian \& Madlberger, 2005).
Consumers in general and recipients in particular can be confused about the volume of information mobile advertising provides and it can be considered an invasion of mobile users' privacy (Stewart \& Pavlou, 2002). And when people are addressed by advertisements, the humiliation they get will cause a very significant impact on their attitudes toward mobile advertising (Shavitt et al., 1998). In addition, one of the reasons that make consumers perceive advertisements unpleasantly and uncomfortably is using unattractive, offensive, disrespectful and unscrupulous advertising techniques (Ducoffe, 1996). So, consumers need to have permission and control on what they receive.

Behavioral modeling for smartphone advertising based on consumer behavior research model for Internet advertising (Ducoffe, 1996) consists of four factors: (1) Entertainment, (2) Informativeness, (3) Irritation, and (4) Credibility. Brackett and Carr (2001) used models and added demographic factors. This model is commonly used in some countries for marketing on smart devices and online advertising such as in Taiwan (Tsang et al., 2004) and Bangladesh (Chowdhury et al., 2010).

Brackett and Carr (2001) pointed out that the attitudes of consumers towards website advertisements are influenced by two main groups of factors: (1) value that the website promotion program brings, and (2) demographic characteristics of consumers. In particular, the value of the advertising program is governed by four smaller factors:

(1) entertainment nature of the advertising program, (2) value and content of the advertising program, (3) annoyance that the advertisement causes to the website user, and

(4) consumer reliability in the brand and the advertised program. Tsang et al. (2004) added two factors: (5) user permission and (6) promotion value. Xu, Liao and Li (2008) investigated the impact of personalization on customer attitudes towards smartphone advertising in China and added

\section{(7) personalization.}

In Vietnam, the customer attitude model for SMS advertising on smartphones by Van (2013) based on Ducoffe (1996) and Tsang et al. (2004) includes: (1) Entertainment,

(2) Informativeness, (3) Irritation, (4) Credibility. The model of factors affecting young consumers' attitudes towards SMS advertising by Huong and Minh (2014) includes: (1) Perceived benefits, (2) Perceived interest, (3) Credibility, (4) Permission and control, and (5) Perceived irritation. Research on the impact of mobile marketing on the attitudes of smart consumers behavior when receiving advertising in HoChiMinh City by Loi (2013) reveals the following factors: (1) Informativeness, (2) Promotional value, (3) Reliable value, (4) Irritation, (5) Recreational value, and (5) Social value. The current research (Cho, Binh, \& Giang, 2016; Linh \& Ha, 2016) agreed with the previous research findings. 


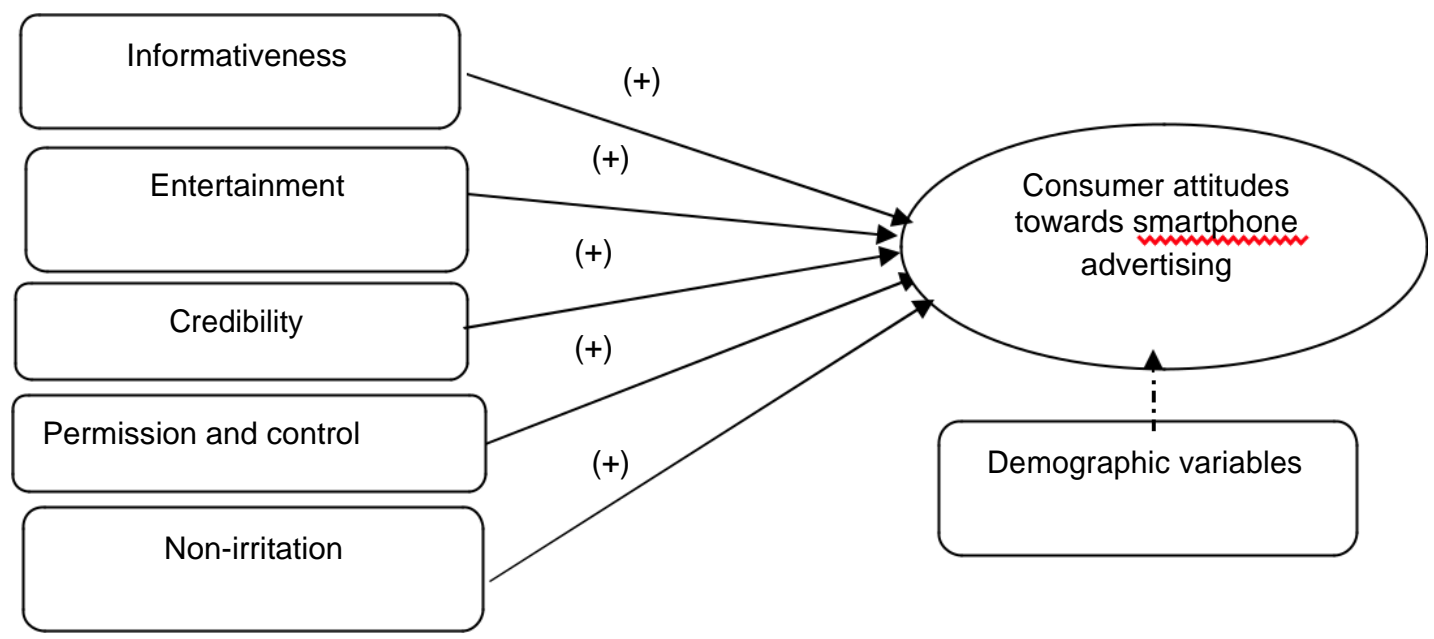

Figure 1: Proposed research model

\subsection{Proposed Research Model}

Inheriting Tsang et al. (2004) and the previous studies, the proposed model is adapted from the Vietnamese research and shown in Figure 1, and the hypotheses are as follows:

H1: The perceived informativeness of mobile advertising has a positive effect on attitude toward smartphone advertising

$\mathbf{H}_{2}$ : The perceived entertainment of mobile advertising has a positive effect on attitude toward smartphone advertising

H3: The perceived credibility of mobile advertising has a positive effect on attitude toward smartphone advertising

H4: The perceived permission and control of mobile advertising has a positive effect on attitude toward smartphone advertising

H5: The perceived non-irritation of mobile advertising has a positive effect on attitude toward smartphone advertising

\section{Research Results}

\subsection{Characteristics of Survey Samples}

The questionnaire for this study comprised 25 question items. A questionnaire was designed in Vietnamese, using a 5-point Likert scale ( 1 = strongly disagree, 2 = somewhat disagree, 3 = neither agree nor disagree, $4=$ somewhat agree, $5=$ strongly agree). The study uses the online survey form via e-mail and Facebook in a convenience sampling method, the subjects surveyed are between the ages of 18 and 35, and are students and office workers in the urban areas of the big cities in Vietnam, Hanoi city, Danang city, and HoChiMinh city, where smartphones customers often use $3 \mathrm{G}, 4 \mathrm{G}$, wifi to access the internet, and other phone applications, 514 questionnaires were collected, of which 490 were valid and used for processing. Respondents' characteristics shown in Table 1.

Table 1: Survey sample characteristics

\begin{tabular}{|l|l|c|c|}
\hline \multicolumn{2}{|c|}{ Sample information } & Quantity & Ratio (\%) \\
\hline \multirow{2}{*}{ Gender } & Male & 226 & 46.1 \\
\cline { 2 - 4 } & Female & 264 & 53.9 \\
\hline \multirow{2}{*}{ Age } & $18-21$ & 251 & 51.2 \\
\cline { 2 - 4 } & $22-35$ & 239 & 48.8 \\
\hline \multirow{2}{*}{$\begin{array}{l}\text { Academic } \\
\text { level }\end{array}$} & High School to Intermediate & 146 & 29.8 \\
\cline { 2 - 4 } & College \& Undergraduate & 234 & 47.8 \\
\cline { 2 - 4 } & Postgraduate & 110 & 22.4 \\
\hline \multirow{4}{*}{ Income } & Under 5 million VND/month & 64 & 13.0 \\
\cline { 2 - 4 } & 5 million - less than 10 million VND/month & 195 & 39.8 \\
\cline { 2 - 4 } & 10 million - less than 20 million VND/month & 141 & 28.8 \\
\cline { 2 - 4 } & Over 20 million VND/month & 90 & 18.4 \\
\hline
\end{tabular}


Table 2: Cronbach's Alpha scale result

\begin{tabular}{|c|l|c|c|c|c|}
\hline No. & \multicolumn{1}{|c|}{ Scale } & Symbol & Quantity & $\begin{array}{c}\text { Cronbach's } \\
\text { Alpha }\end{array}$ & $\begin{array}{c}\text { Smallest Item-Total } \\
\text { Correlation }\end{array}$ \\
\hline 1 & Informativeness & INF & 4 & 0.815 & 0.493 \\
\hline 2 & Entertainment & ENT & 5 & 0.846 & 0.657 \\
\hline 3 & Non-irritation & NIRR & 5 & 0.864 & 0.671 \\
\hline 4 & Credibility & CRE & 4 & 0.728 & 0.459 \\
\hline 5 & Permission and control & PRC & 4 & 0.774 & 0.613 \\
\hline 6 & $\begin{array}{l}\text { Attitude towards smartphone } \\
\text { advertising }\end{array}$ & ATT & 3 & 0.841 & 0.708 \\
\hline
\end{tabular}

\subsection{Assessing the Reliability of the Scale}

The results of the Cronbach's Alpha scales (Table 2) showed that the scales met Cronbach's Alpha reliability score of 0.6 and the total correlation coefficient was $>0.3$, all observed variables of the scales met the conditions for EFA (Giao \& Vuong, 2019).

\subsection{Exploratory Factor Analysis - EFA}

Factor analysis was performed with the Principle Component extraction and Varimax rotation for 23 observed variables. Factor analysis showed that the coefficient KMO $=0.897$, which was satisfactory $\geq 0.5$; the significance level of the Bartlett test is $0.000 \leq 0.05$; the total variance was $65,707 \%$; factor loading is $>0.5$, should meet requirements (Giao \& Vuong, 2019). The official EFA process scale consists of 21 observed variables (removing NIRR5) as shown in Table 3.

The analysis of the dependent variable was $65.707 \%$ at the first factor analysis, and the observed variables have factor loadings greater than 0.5 and sig. value of Bartlett's was 0.000 $<0.05$. Thus, observed variables of the dependent variable will be further analyzed (Giao \& Vuong, 2019).

\subsection{Linear Regression Model}

The results from the Pearson correlation matrix showed that the correlation coefficients were statistically significant (Sig. < 0.01), so all variables will be used in the regression analysis in the next step. The result shows that adjusted $\mathrm{R}_{2}$ is $51 \%$, which means that the model with 5 independent variables explains $51 \%$ the variability of the attitude towards smartphone advertising and the other $49 \%$ is due to variables of other models that this study has not mentioned.

Table 4 shows the sig. value of the model is very small compared to the significance level (sig. $=0.000<0.05$ ), so the model fits the data set and can be generalized to the whole. Table 6 shows the sig. value of independent variables were significantly lower than the significance level of 0.05 , meaning that independent variables have high correlation, significantly affecting the dependent variable. The standardized beta regression coefficients have a positive

Table 3: Results of rotation matrix

\begin{tabular}{|l|c|c|c|c|c|}
\hline \multirow{2}{*}{} & \multicolumn{5}{|c|}{ Factor } \\
\hline & 1 & 2 & 3 & 4 & 5 \\
\hline NIRR3 & 0.824 & & & & \\
\hline NIRR2 & 0.753 & & & & \\
\hline NIRR1 & 0.747 & & & & \\
\hline NIRR4 & 0.745 & & & & \\
\hline ENT3 & & 0.801 & & & \\
\hline ENT2 & & 0.718 & & & \\
\hline ENT4 & & 0.732 & & & \\
\hline ENT1 & & 0.647 & & & \\
\hline ENT5 & & 0.634 & & & \\
\hline CRE2 & & & 0.783 & & \\
\hline CRE3 & & & 0.764 & & \\
\hline CRE1 & & & 0.745 & & \\
\hline CRE4 & & & 0.656 & & \\
\hline PRC2 & & & & 0.881 & \\
\hline PRC4 & & & & 0.758 & \\
\hline PRC1 & & & & 0.732 & \\
\hline PRC3 & & & & 0.762 & \\
\hline INF4 & & & & & 0.759 \\
\hline INF1 & & & & & 0.631 \\
\hline INF2 & & & & & 0.646 \\
\hline INF3 & & & & & 0.678 \\
\hline
\end{tabular}


Table 4: Results of statistical tests for regression coefficients

\begin{tabular}{|c|c|c|c|c|c|c|c|}
\hline & \multicolumn{2}{|c|}{ Unstandardized coefficient } & \multirow{2}{*}{$\begin{array}{c}\begin{array}{c}\text { Standardized } \\
\text { coefficient }\end{array} \\
\text { Beta } \\
\end{array}$} & \multirow{2}{*}{$t$} & \multirow{2}{*}{$\begin{array}{c}\text { Sig. } \\
\text { (Level of } \\
\text { significane) } \\
\end{array}$} & \multicolumn{2}{|c|}{ Multicollinearity } \\
\hline & B & Standard error & & & & Tolerance & VIF \\
\hline Constant & -0.467 & 0.252 & & -1.853 & 0.065 & & \\
\hline INF & 0.245 & 0.061 & 0.227 & 3.938 & 0.000 & 0.554 & 1.805 \\
\hline ENT & 0.351 & 0.062 & 0.332 & 5.644 & 0.000 & 0.517 & 1.933 \\
\hline NIRR & 0.171 & 0.060 & 0.151 & 2.745 & 0.006 & 0.556 & 1.797 \\
\hline CRE & 0.203 & 0.058 & 0.184 & 3.518 & 0.001 & 0.648 & 1.542 \\
\hline PRC & 0.125 & 0.048 & 0.113 & 2.878 & 0.004 & 0.993 & 1.007 \\
\hline \multicolumn{8}{|c|}{$\begin{array}{l}\text { Adjusted R2: } 0.574 \\
\text { Durbin-Watson Coefficient: } 1.537 \\
\text { Statistics F (ANOVA): } 72.612 \\
\text { Level of Significance (Sig. of ANOVA): } 0.000\end{array}$} \\
\hline
\end{tabular}

value, i.e. they affect the dependent variable positively. Thus, the model is consistent with the original hypotheses, the hypotheses $\mathrm{H}_{1}, \mathrm{H}_{2}, \mathrm{H}_{3}, \mathrm{H}_{4}, \mathrm{H}_{5}$ are accepted (Giao \& Vuong, 2019). The level of impact is as follows: (1) Entertainment, (2) Informativeness, (3) Credibilty, (4) Permission and control, and (5) Non-irritation. Thus, the regression model at this time will be rewritten as follows:

Attitude towards smartphone advertising $=-4.67+$ $0.240 *$ Informativeness $+0.351 *$ Entertainment +0.166

$*$ Non-irritation $+0.203 *$ Credibility $+0.137 *$ Permission and control $+\mathrm{e}$

As regards detection of violations of linear regression models, the scatterplot shows that the residuals do not change in any order for the predicted value, they disperse randomly, so the hypothesis of multicollinearity is not violated. As regards Spearman correlation coefficients of absolute values of residuals and independent variables, Sig. values of correlation coefficients with $95 \%$ confidence intervals are greater than 0.05 , indicating that the variance of the error remains unchanged, assuming no violation. The histogram shows the normal distributed residual with a mean value close to zero (Mean $=1.43 \mathrm{E}-15$ ) and its standard error is close to 1 (0.989). The P-P plot shows actual observation is quite close to the diagonal of the expected values, which means that the residual data has a standard distribution. Coefficient $1<$ Durbin Watson $=1.448$

$<3$ is satisfactory, the VIF $<10$ indicates that the independent variables are not closely related so there is no multicollinearity. Thus, the linear regression model constructed by the above equation does not violate the assumptions required in linear regression (Giao \& Vuong, 2019).

\subsection{Difference Testing}

In terms of gender, the Independent-samples T-test showing that the Levene Test was performed first with the sig. result $=0.09>0.05$ indicates the variance of the mean of attitudes towards advertisement has a standard distribution so sig. of the $t$ test is calculated as $0.184>$ 0.05 , with no difference in attitudes towards smartphone advertising between men and women.

In terms of age, Levene test results with sig. coefficient $=0.883>0.05$, i.e. this variance has a standard distribution. Analyzing results of ANOVA sig. $=0.782>0.05$, there is no difference in attitudes towards smartphone advertising among age groups.

In terms of academic level, the sig. of Levene's test is $0.01<0.05$. This means that the variance of the groups has no standard distribution or variance of the different groups, in addition the ANOVA sig. coefficient is $0.002<0.05$, academic level is different from smartphone advertising. Tamhane's T2 test shows a clear difference among the different academic levels.

In terms of income, the sig. coefficient $=0.072>0.05$ i.e. this variance has a standard distribution. Analysis results of ANOVA sig. $=0.00<0.05$, there is a difference among income groups for attitudes towards smartphone advertising. Dunnet's test shows that there are differences among the three different income groups for the attitudes towards smartphone advertising (Giao \& Vuong, 2019).

\section{Managerial Implication and Conclusion}

\subsection{Managerial Implications}

\subsubsection{Entertainment Factor}

This is the most influential factor in the model with a high standardized coefficient of 0.332 , and this significant factor has a positive trend with mean $=3.358$. This proves that entertainment is one of the factors that influence the attitudes. The highly entertaining content of advertisement, the humorous and familiar way of conveying the advertisement 
will easily enter the mind of the customers. The factors that affect the entertainment include: fun, relaxation, comfort, entertainment, being eye-catching, and satisfaction.

Being eye-catching (mean $=3.57)$ and the satisfaction $($ mean $=$ 3.72) are highly evaluated factors. Besides fun, comfort and relaxation factors have means of $3.09 ; 3.21 ; 3.22$, respectively. This shows that the advertisement does not merely bring the product/service information to the customer, but the eye-catching form and content of the advertisement also makes the customer happy, interested in the advertisement more.

Smartphone advertising is now primarily advertising in the form of banners. Because of the very limited interface and size of advertising, in order to be highly effective, the marketers should pay attention to investment in quality, value, entertaining, humorous and relaxing content, which will appeal to the consumer. Consumers are becoming increasingly intelligent and not so easy-going, so only ads that have new and unique ideas or meet the needs of customers can attract the attention of viewers. If necessary, it can be combined with sound and images to create lively ads, especially to touch the emotions of the audience and attract the attention of customers, so that they feel that advertising has a certain value in their hearts.

\subsubsection{Informativeness Factor}

This is a factor that has a second impact on attitudes with a high standardized coefficient of 0.227 , and has a positive affect on attitudes. This means when smartphone advertising provides more relevant information to the consumer, the more positive attitudes they receive from them. Attitudes towards information reached an average of 3.16. It can be stated as follows, smartphone advertising information is not comprehensive compared to the advertising on the web of the business. With the previous practice, when looking for a product/service, consumers will come directly to the website of the business to have full and accurate information. Impact factors include: timely information, the information I need, increased knowledge of products/services, convenient channels to learn about products and services.

In general, consumers do not really appreciate the value of information that smartphone advertising brings, the mean values here are only from 3.02 to 3.04. Consumers believe that today, the information is provided quite widely and in many different ways. For example, when a business launches a new product, it can advertise on television, through newspaper, online, Facebook, etc. The smartphone is just only a small part of that source of information. And the fact is, only when they need it, they actively seek out the business website and they may not need advertising via smartphone but through these ads they have the opportunity to know products, services and create or stimulate demand for them. Therefore, businesses should provide information products and services regularly and continuously to attract the concern and attention of consumers.

Smarthone advertising is also said to increase the knowledge of the products/services, which is a convenient way to find out more about them for consumers. With the current pace of industrial development, the product/ service sector is constantly innovating. Therefore, the form of smartphone advertising is also one of the means to give consumers easy access to the most regularly updated programs. Therefore, smartphone advertising is considered effective, besides the humor and entertainment brought about, the content of advertising is considered important because it will determine whether the consumer continues to be interested and learn more about the products/services or not. Managers should focus on expressing and presenting information in the shortest, closest and easy-to-understand way that will help keep it in the customer's mind.

\subsubsection{Credibility Factor}

The analysis confirms that the Credibility factor is the third most influential factor with a standardized coefficient of 0.184 , and a positive mean of 3.24. This factor has a positive impact on consumer attitudes towards smartphone advertising. This means that the higher the trustworthiness users have for a smartphone ad, the more positive attitude they have for the advertisements. The impact factors include: referral channels for purchase, trustworthy adverts, trust in smartphone advertisements, and contribution to purchase decisions.

The "contribution to the purchase decision" factor has the highest mean value (3.34), and the remaining have mean value from 3.16. to 3.23. Through preliminary surveys, consumers think that the Internet-related environment is a free environment, that every individual or business has freedom of speech, and any individual or organization can post. Advertising is the main reason, so the authenticity and reliability of the information is not guaranteed, making it difficult for consumers to know which advertisement is reliable, and vice versa. So, smartphone advertising is also among the sources of information that is not reliable. This is just one of the sources of information in their buying process, as consumers may inadvertently know about the product. However, to make the purchase decision, consumers still have many steps to learn other information.

Advertising not only helps businesses bring their brands/ products/services closer to the public, but also influences the choice of the consumer's products, thus creating confidence through advertising. It is the first step for a business to create a place in the heart of customers. The trustworthiness that consumers get from smartphone advertising can be from personal experience or the introduction by relatives and friends. By direct access to consumers through smartphones to create closeness, friendliness, understanding between 
businesses and consumers, understanding consumers, businesses will bring value to people. Consumers have since gained their trust. Once they have their trust, getting more customers from the people around them will be easier.

\subsubsection{Non-irritation Factor}

This factor is the one that has a positive impact and has the fourth highest influence among the five factors, with standardized coefficient of 0.151 . This means that, the higher the irritation, the better the positive attitude of the consumer. However, this is the factor with the lowest mean value of 3.11, which means that the consumer attitude is not really good for this factor. Factors affecting non-irritation include: not annoying, multi-time appearance, not causing trouble, and not causing offence to viewers, that have mean levels ranging from 3.07 to 3.22 .

Consumers have the right to choose whether they are proactive, not passive. At the same time, smartphone advertising policies are always adjusted to limit the annoyance affecting the user. In addition, the technique of smartphone advertising is always improved and gradually more user friendly. Therefore, they do not feel bothered or annoyed when the advertisements appear. Smartphone advertising directly interacts with customers, therefore, managers should build appropriate advertising strategies that will make them comfortable and not annoyed. Attention drawing techniques are needed, however, businesses or individuals should not be overly abusive, otherwise they would be counterproductive or annoying for customers.

\subsubsection{Permission and Control Factor}

The results of the analysis show that the permission and control factor has the lowest impact and positive impact on attitude towards smartphone advertising with standardized coefficient of 0.113 . However, this is the most reliable factor out of all five factors with significant mean $=3.48$, and has a relatively high significance for consumers. This is understandable because with consumers using the phone, mastering every advertisement, all the annoying factors, being in control and mastering the advertisements themselves will make them more comfortable. Factors that affect permission and control include: advertisement content is not annoying, advertising is not offensive, and advertising does not offend the viewer.

The "may refuse to accept advertising" factor has the highest level of significance in the 22 observed variables of the model. When they learn more about consumers, they are interested in the core elements at the right time. In other words, if consumers can actively reject or receive advertisements according to their individual needs, they will appreciate the advertisements. In addition to the above factors, the other factors also play an important role when the reliability is relatively high, in which the non-irritation factor has an average mean $=3.46$, the non-aversion cause factor has mean $=3,34$ and lastly the not causing offence to viewers factor has an average $=3.42$. Most customers think that every day they have too many advertisements by phone such as SMS advertising, advertising via email, advertising through the Internet when watching news, advertising when surfing Facebook to relax. The vast majority of advertisements leave them feeling uncomfortable to watch. They still appreciate advertisements with the consumer's permission.

Therefore, to maximize the effectiveness of the advertisements, marketers should study the appropriate forms of advertising, which allow consumers to refuse or control any advertisements. Businesses should also use tools that can filter the right customers, study the consumer behavior towards smartphones to have pratical approaches of smartphone advertising.

\subsubsection{Demographic Factor}

The analysis of the four demographic factors shows that there are two main differences among groups of income and academic level. For income, there are differences in attitudes among income group below VND5 million per month, income group from VND5 to 10 million and group from VND10 to less than 20 million. This is also understandable, income is also one of the consumption behavior decisions of consumers. For people with an income of less than VND5 million income, they are interested in the products they need and the price that is appropriate for their lives. In contrast to those with high incomes, consumption behavior is not the same as for low income groups, they do not overemphasize the price; the choice of a suitable product/service is more important. Therefore, when businesses segment the brand/ product/service by income, attention should be paid to the message conveyed for each group as well as how to express that message in advertising terms. This difference also helps businesses to develop different advertising strategies for different income groups.

For consumers with university diplomas, this is a significant difference. At each level, the perception of each person will be different. Low academic level people tend to be more interested in advertising, are more likely to be fooled by the business, and the way to make a purchase or decision is different. Proficiency will be proportional to age, so higher-level graduates will be more experienced and may have more scholarly and shared views, thoughts and attitudes with the other group, so when the advertisement directs to this object, it is necessary to study the advertising content more appropriately. A product that target a low academic level audience needs terms that are easy to understand, familiar to describe the product/service message. Conversely, advertisements that are aimed at high-qualified audiences must have a high-quality, scientific, textual content 
that is relevant to the recipient. Consumers appreciate and have more positive attitude towards smartphone advertising.

\subsection{Conclusion}

The study used a convenient sampling method, 490 responses met the requirement for data analysis and processing. After evaluating Cronbach's alpha reliability, and analyzing the EFA, five factors were identified as the proposed model. The result of linear regression model with adjusted $\mathrm{R}_{2}$ of $57.4 \%$. Unstandardized regression model:

Attitude towards smartphone advertising $=-4.67+0.240$

* Informativeness $+0.351 *$ Entertainment $+0.166 *$ Nonirritation $+0.203 *$ Credibility $+0.137 *$ Permission and control $+\mathrm{e}$

All hypotheses are accepted. The independent variables have a positive impact on Vietnamese consumer' attitudes toward smartphone advertising. The results show that demographic variables of income and academic level are different for attitudes towards smartphone advertising in Vietnam, except for gender and age. The level of impact of in dependent variables is reduced as follows: (1) Entertainment, (2) Informativeness, (3) Credibility, (4) Permission and control, and (5) Non-irritation.

\subsection{Limitations of the Research}

The study has some limitations: (1) the research was conducted only in the three big city: Hanoi city, Danang city, Ho Chi Minh City, specifically at some universities and office staff, so representativeness is limited, (2) the research used non-probability convenient sampling method, resulting in not so high representativeness, and (3) the research may not yet cover other aspects that affect consumer attitudes towards smartphone advertising such as interactivity, personalization, purchase decisions, and so on. These are suggestions for future researches.

\section{References}

Aaker, D. A., \& Bruzzone, D. E. (1985). Causes of irritation in advertising. Journal of Marketing, 49(2), 47-57. http://dx.doi. org/10.2307/1251564

Altuna, O. K., \& Konuk, F. A. (2009). Understanding consumer attitudes toward mobile advertising and its impact on consumers' behavioral intentions: A cross-market comparison of United States and Turkish consumers. International Journal of Mobile Marketing, 4(2), 43-51.

Brackett, L. K., \& Carr, B. N. (2001). Cyberspace Advertising vs. Other Media: Consumer vs. Mature Student Attitudes. Journal of Advertising Research, 41(5), 23-32.

Carroll, A., Barnes, S. J., Scornavacca, E., \& Fletcher, K. (2007). Consumer perceptions and attitudes towards SMS advertising:
Recent evidence from New Zealand. International Journal of Advertising, 26(1), 79-98.

Chakrabarty, S., \& Yelkur, R. (2005). The Effects of Ad Irritation on Brand Attitudes. Journal of Promotion Management, 11(2), 37-48. DOI: 10.1300/J057v11n02_04

Cheng, J. M., Blankson, C., Wang, E. S., \& Chen, L. S. (2009). Consumer attitudes and interactive digital advertising. International Journal of Advertising, 28(3), 501-525. http:// dx.doi.org/10.1002/mar.20237

Cho, J., Binh, L. D., \& Giang, V. T. H. (2016). The impact of mobile advertising on Vietnamese consumer buying decision. International Journal of Research Studies in Management, 5(1), 3-18.

Chowdhury, H. K., Parvin, N., Weitenberner, C., \& Becker, M. (2010). Consumer attitude toward mobile advertising in an emerging market: An empirical study. Marketing, 12(2), 206216.

Ducoffe, R. H. (1995). How consumers assess the value of advertising. Journal of Current Issues and Research in Advertising, 17(1), 1-18. http://dx.doi.org/10.1080/10641734.1995.10505022

Ducoffe, R. H. (1996). Advertising Value and Advertising on the Web. Journal of Advertising Research, 36(5), 21-35.

Ercis, S. U. A., \& Ercan, K. (2011). Attitudes towards mobile advertising - A research to determine the differences between the attitudes of youth and adults. Procedia Social and Behavioral Sciences, 24, 361-377. http://dx.doi.org/10.1016/j. sbspro.2011.09.067

Giao, H. N. K., \& Vuong, B. N. (2019). Giáo trình Cao hoc Phuoong pháp Nghiên cúu Khoa học trong Kinh doanh- Cập nhật SmartPLS. Nhà xuất bản Tài chính. Hà Nội. DOI: 10.31219/osf.io/hbj3k. ISBN: 978-604-79-2154-6

Giao, H. N. K. (2018a). Sách chuyên khảo Đo luờng chất luợng dịch vu tại Việt Nam- nhìn tù̀ phía khách hàng. Nhà xuất bản Tài chính. Hà Nội. DOI: 10.31219/osf.io/cqh68. ISBN: 978604-79-1788-4

Giao, H. N. K. (2018b). Vietnamese consumers' attitude on television advertisement of skin care. National Academy of Managerial Staff of Culture and Arts Herald, 4, 486-491. Retrieved from http://jrhnamsca.icu/index.php/hnamsca/issue/ view/1. DOI: 10.31219/osf.io/a2bn9.

Giao, H. N. K., Hoai, A. T., \& Vinh, P. Q. (2019). Quản trị Kinh doanh Dịch vu- Tù Góc nhìn Marketing. Nhà xuất bản Truyền thông Thông tin Hà Nội. DOI: 10.31219/osf.io/98hrd. ISBN: 978-604-80-3905-9

Giao, H. N. K., Vuong, B. N., \& Quan, T. N. (2019). The influence of website quality on consumer's e-loyalty through the mediating role of e-trust, esatisfaction, and perceived enjoyment: An evidence from online shopping in Vietnam. Uncertain Supply Chain Management, 8(2), 351-370. DOI: 10.5267/j.uscm.2019.11.004. http://www.growingscience.com/ uscm/Vol8/uscm_2019_42.pdf.

Haghirian, P., \& Madlberger, M. (2005). Consumer attitude toward advertising via mobile devices - an empirical investigation among Austrian users. Proceedings of the 13th European Conference on Information Systems, Information Systems in a Rapidly Changing Economy. Regensburg, Germany: ECIS. 
Heikki, K., \& Matti, L. (2005). Factors influencing consumers' willingness to accept mobile advertising: a conceptual model. International Journal of Mobile Communications, 3(3), 197-213.

Huong, P. T. L., \& Minh, T. N. P. (2014). Factors affecting youth consumers' attitude towards SMS advertising. Journal of Economic Development, 286, 89-108.

Jun, J., Lee, J. W., \& Jung, J. (2019). The Mediating Roles of Trust and System Quality in Achieving System Success: A System Integrator Perspective. Journal of Asian Finance, Economics and Business, 6(2), 203212.https://doi.org/10.13106/ jafeb.2019.vol6.no2.203.

Kaplan, A. (2012). If you love something, let it go mobile: Mobile marketing and mobile social media 4x4 Found. Business Horizons, 55(2), 129-139.

Kotler, P., Keller, K. L., Ang, S. H., Tan, C. T., \& Leong, S. M. (2018). Marketing management: an Asian perspective (5th ed). London, United Kingdom: Pearson Education

Kussusanti, S., Tjiptoherijanto, P., Halim, R. E., \& Furinto, A. (2019). Informational Justice and Post-recovery Satisfaction in E-Commerce: The Role of Service Failure Severity on Behavioral Intentions. Journal of Asian Finance, Economics and Business, 6(1), 129-139. http://doi.org/10.13106/ jafeb.2019.vol6.no1.129.

Lee, J. W., Kwag, M., \& Potluri, R. M. (2015). Antecedents of Acceptance of Social Networking Sites in Retail Franchise and Restaurant Businesses. Journal of Asian Finance, Economics and Business, 2(1), 29-36. https://doi.org/10.13106/jafeb.2015. vol2.no1.29.

Linh, N. K., \& Ha, N. T (2016). Consumer Attitude towards Marketing Practices in Vietnamese Smartphone Market. VNU Journal of Science: Economics and Business, 32(2), 24-34.

Loc, X., \& Giang, H. (2019). Ministry of Information and Communications reviews the first 6 month activities and looks forward into the last 6 months activities. Retreived December 20, 2019, from http://www.mic.gov.vn/Pages/TinTuc/139313/ Bo-TT-TT-so-ket-cong-tac-6-thang-dau-nam-va-phuonghuong-nhiem-vu-6-thang-cuoi-nam-2019.html.

Loi, H. H. (2013). Research on the affects of Mobile Marketing on the attitude of smart consumers behavior when receiving advertising (Master Thesis). University of Economics Ho Chi Minh City, Ho Chi Minh City, Vietnam.

Lutz, R. J. (1985). Affective and Cognitive Antecedents of Attitude towards the Ad: A Conceptual Framework. In L. F. Alvitt \& A. A. Mitchell (Eds), Psychological Processes and Advertising Effects (pp.45-64). Hillsdale, NJ: Lawrence Erlbaum Associates.

MacKenzie, S. B., \& Lutz, R. J. (1989). An empirical examination of the structural antecedents of attitude toward the ad in an advertising pretesting context. Journal of Marketing, 53, 4865. http://dx.doi.org/10.2307/1251413

Matti, L. (2008). Mobile marketing communications in consumer markets. Oulu, Finland: University of Oulu.

McQuail, D. (1983). Mass communication theory: An introduction. London, United Kingdom: Sage.
Rettie, R., Grandcolas, U., \& Deakins, B. (2005). Text message advertising: Response rates and brand effects. Journal of Targeting, Measuring and Analysis for Marketing, 13(4), 304312. http://dx.doi.org/10.1057/palgrave.jt.5740158

Shavitt, W., Lowrey, P., \& Haefner, J. (1998). Public attitudes towards advertising: More favorable than you might think. Journal of Advertising Research, 38(4), 7-22.

Solomon, M. R. (2004). Consumer Behavior: Buying, Having and Being (6th ed.). Upper Saddle River, NJ: Pearson-Prentice Hall.

Stewart, D. W., \& Pavlou, P. A. (2002). From consumer response to active consumer: measuring the effectiveness of interactive media. Journal of the Academy of Marketing Science, 30(4), 376-396. http://dx.doi.org/10.1177/009207002236912

Tham, K. W., Dastane, O., Johari, Z. \& Ismail, N. B. (2019). Perceived Risk Factors Affecting Consumers' Online Shopping Behaviour. The Journal of Asian Finance, Economics and Business, 6(4), 246-260. DOI:https://doi.org/10.13106/jafeb.2019.vol6.no4.249.

Tsang M. M., Ho, S. C., \& Liang, T. P. (2004). Consumer Attitudes Toward Mobile Advertising: An Empirical Study. International Joural of Electronic Commerce, 8(3), 65-78.

Unal, S., Erics, A., \& Keser, E. (2011). Attitudes towards mobile advertising - A research to determine the differences between the attitudes of youth and adults. Procedia Social and Behavioral Sciences, 24, 361-377. http://dx.doi.org/10.1016/j. sbspro.2011.09.067

Van, T. T. T. (2013). Factors affecting customers attitude in HoChiMinh City towards SMS Advertising on smartphone (Master Thesis). University of Economics Ho Chi Minh City, Ho Chi Minh City, Vietnam.

Vuong, B. N., \& Giao, H. N. K. (2019). The impact of brand globalness on consumers purchase intention and the moderating role of consumer ethnocentrism an evidence from Vietnam. Journal of International Marketing, 32(1), 47-68. DOI: 10.1080/08961530.2019.1619115.

Wanmo, K. B. S. (2010). Generation Y attitudes toward mobile advertising: Impacts of modality and culture (Unpublished master's thesis for master's degree). University of North Texas, Denton, Texas.

Wong, M. M. T., \& Tang, E. P. Y. (2008). Consumers' attitudes towards mobile advertising: The role of permission. Review of Business Research, 8(3), 181-187.

Xu D. J., Liao, S. S., \& Li, Q. (2008). Combining empirical experimentation and modeling techniques: A design research approach for personalized mobile advertising applications. Decision Support Systems, 44(3), 710-724.

Zabadi, A., Shura, M., \& Elsayed, E. (2012). Consumer attitudes toward SMS advertising among Jordanian users. International journal of marketing studies, 4(1), 77-94. http://dx.doi. org/10.5539/ijms.v4n1p77

Zoller, E., Housen, V. L., \& Matthews, J. (2001). Wireless internet business models: Global perspective, regional focus. London, United Kingdom: Ovum Ltd. 